\title{
KLASIFIKACIJA IZGOVORNIH ODSTUPANJA NA POČETNOM STUPNJU UČENJA HRVATSKOGA - GLOTODIDAKTIČKI PRISTUP
}

\author{
Mateja Šporčić \\ Veleučilište Baltazar Zaprešić
}

\begin{abstract}
Suvremeni je pristup poučavanju J2 usredotočen na stjecanje komunikacijske kompetencije, čija je sastavnica i izgovorna kompetencija. Kako bi se stekla odgovarajuća izgovorna kompetencija, važno je uklanjati izgovorna odstupanja, kojima se može sustavno pristupiti ponajprije njihovim opisom, analizom i klasifikacijom. Ovaj rad pokušava dati jednostavnu klasifikaciju izgovornih odstupanja, primjenjivu na izgovor hrvatskoga kao J2 neovisno o polaznim jezicima učenika, u koju se mogu uklopiti različite pojave na početnim stupnjevima učenja. Primjeri odstupanja ekscerpirani su iz snimaka usmene proizvodnje i govornog međudjelovanja učenika nakon 30 - 45 sati formalnog učenja hrvatskoga kao drugog jezika. Klasificirane i opisane pojave mogu se očekivati na podrazinama učenja A1.1 i A1.2, a podijeljene su na ortoepska, fonološka, koartikulacijska, fonetska i naglasna odstupanja. Takva podjela pruža okvir za odlučivanje o redoslijedu otklanjanja odstupanja te za odabir odgovarajućih metoda poučavanja.
\end{abstract}

Ključne riječi: izgovorna odstupanja, hrvatski kao J2, fonološka odstupanja, fonetska odstupanja.

\section{UVOD}

Poučavanjeinogajezikanajčešće započinjeupoznavanjemučenika sgrafijskim i glasovnim sustavom ciljanoga jezika kako bi ih se osposobilo za samostalno čitanje grafema i izgovor glasova toga jezika. Učenici koji ujedno i borave u okolini koja se služi ciljanim jezikom taj jezik i spontano usvajaju, pri čemu do primarnog susreta s drugim jezikom, ${ }^{1}$ prije početka samog (in)formalnog učenja jezika, obično dolazi posredstvom zvuka, tj. govora bez obzira na to bio to jezik okoline $u$ kojoj učenik J2 odrasta ili jezik okoline $u$ koju se trajno ili privremeno doseljava. S druge strane, učenici koji uče J2 kao strani jezik, dakle u sredini koja tim jezikom ne govori, na početku ovladavanja jezikom susreću se s riječima novoga jezika ponajprije posredstvom pisanih nastavnih materijala, uz nastavnika i nastavne audiomaterijale kao izvor zvučnog inputa. No, bez obzira na to ovladavaju li učenici inim jezikom

\footnotetext{
msporcic@bak.hr

${ }^{1}$ Termin „drugi jezik“ upotrebljava se u značenju koje mu pridaje Jelaska (2005), prema kojemu je to „bilo koji novi jezik kojim osoba ovladava u zajednici gdje se njime služi“ (Jelaska, 2005: 27), dok je prototipni strani jezik onaj koji se uči u školi ili na tečajevima u zemlji u kojoj se njime ne služi (Jelaska, 2005: 29). Stranom i drugom jeziku nadređen je termin „ini jezik“.
} 
u okolini koja se služi tim jezikom ili ne, nastavnici hrvatskoga kao inoga jezika složit će se s time da ovladavanje fonološkom i fonetskom sastavnicom jezične kompetencije, odnosno izgovornom kompetencijom na početnim stupnjevima učenja hrvatskoga predstavlja za mnoge učenike pravi izazov.

Suvremeni pristupi poučavanju inom jeziku polaze od pretpostavke da je osnovni cilj poučavanja i učenja jezika ostvarivanje uvjeta za kompetentno komuniciranje na ciljanom jeziku. S obzirom na to da je komunikacijski pristup trenutačno dominantan i u teorijskim proučavanjima i u praksi poučavanja J2, a pristup je obrazovanju sve više kompetencijski (Ćatić, 2012), u promišljanju ciljeva, sadržaja i metoda poučavanja inog jezika sve se više govori o komunikacijskoj kompetenciji, a poželjno je da odabir nastavnih sadržaja i metoda bude u službi stjecanja upravo te kompetencije.

Glavne su sastavnice komunikacijske kompetencije jezična i strategijska kompetencija (Pavičić Takač i Bagarić Medve, 2013). Uz diskursnu i pragmatičku kompetenciju, jedna je od triju sastavnica jezične kompetencije i gramatička kompetencija, a u većini konceptualizacija te komponente važno mjesto pripada fonološkoj kompetenciji, dok se o fonetskoj kompetenciji nešto rjeđe govori. Kao što upućuju Pavičić Takač i Bagarić Medve (2013), tendencija koja je prisutna u svim modelima komunikacijske kompetencije jest ta da se fonološka i fonetska kompetencija ne prikazuju kao njezine zasebne komponente, odnosno da se terminološki ne razgraničavaju. Dijelovi onoga što se $u$ glotodidaktičkoj literaturi koju autorice konzultiraju opisuje terminima "fonološka“, "fonetska“ i "ortoepska kompetencija“ sastavnice su onoga što se na drugome mjestu pokriva terminima „,izgovorna kompetencija“ (usp. Banković-Mandić, 2013). Celce-Murcia i sur. (1995 prema Pavičić Takač i Bagarić Medve, 2013: 112) navode da je ovladavanje fonološkim elementima, među koje ubrajaju segmente (samoglasnici, suglasnici, vrste slogova, promjene i redukcije između susjednih glasova tijekom govora) i suprasegmente (naglašavanje, naglasak, intonacija, ritam), potrebno za dobar izgovor, dok su ortografski elementi (poznavanje slova, podudaranje fonema i grafema, pravopisna pravila i konvencije za uporabu tehnika pisanja i interpunkcije) potrebni za pisanje.

U Zajedničkom europskom referentnom okviru za jezike (ZEROJ) fonološka se kompetencija definira kao sposobnost percepcije i produkcije zvučnih jedinica (fonema) ${ }^{2}$ jezika i njihove realizacije $\mathrm{u}$ određenim kontekstima (alofona); fonetskih obilježja po kojima se razlikuju fonemi (razlikovne karakteristike); fonetskog sastava riječi (struktura sloga, slijed fonema, naglašavanje riječi, ton riječi); rečenične fonetike (prozodija); naglaska i ritma rečenice; intonacije; fonetske redukcije; redukcije samoglasnika; naglašenih i nenaglašenih slogova; asimilacije i elizije (ZEROJ, 2005: 119-

2 ZEROJ (2005) govori o „fonemima“ iako bi, kada je riječ o realizaciji, prikladnije bilo govoriti o glasovima. 
120). Kada se pogleda ta definicija fonološke kompetencije, jasno je da ona obuhvaća pojave koje pripadaju različitim područjima - fonetici i fonologiji, a zajedničko im je da se (ne)ovladanost tim sastavnicama jezične kompetencije manifestira u usmenoj proizvodnji, odnosno govornom međudjelovanju. Dakle, iz navedenog je popisa vidljivo da se u ZEROJ-u ovladanost fonetskim obilježjima govora na ciljanom jeziku promatra kao podsastavnica fonološke kompetencije. Za klasifikaciju predloženu u ovom radu bit će koristan i koncept ortoepske kompetencije, odnosno jedne njezine sastavnice. Ta kompetencija, prema ZEROJ-u (2005: 120-121), pokriva znanja i sposobnosti koja omogućuju ispravno glasno čitanje riječi i teksta u pisanom obliku, pa je u ovom radu za opisivanje odstupanja koja nastaju kao posljedica nedovoljne ovladanosti grafijskim sustavom hrvatskoga korišten termin „ortoepska odstupanja“.

U ovome se radu polazi od pretpostavke da je ovladanost sastavnicama i fonološke i ortoepske kompetencije, kako ih definira ZEROJ, preduvjet za korektan izgovor i za postizanje komunikacijske kompetencije na hrvatskome kao J2. Uvjetovanost stjecanja komunikacijske kompetencije posjedovanjem i fonološke (fonetske), odnosno ortografske (ortoepske) kompetencije, da se poslužimo konceptima koje navode Pavičić Takač i Bagarić Medve (2013), grafički je predočena na slici 1.

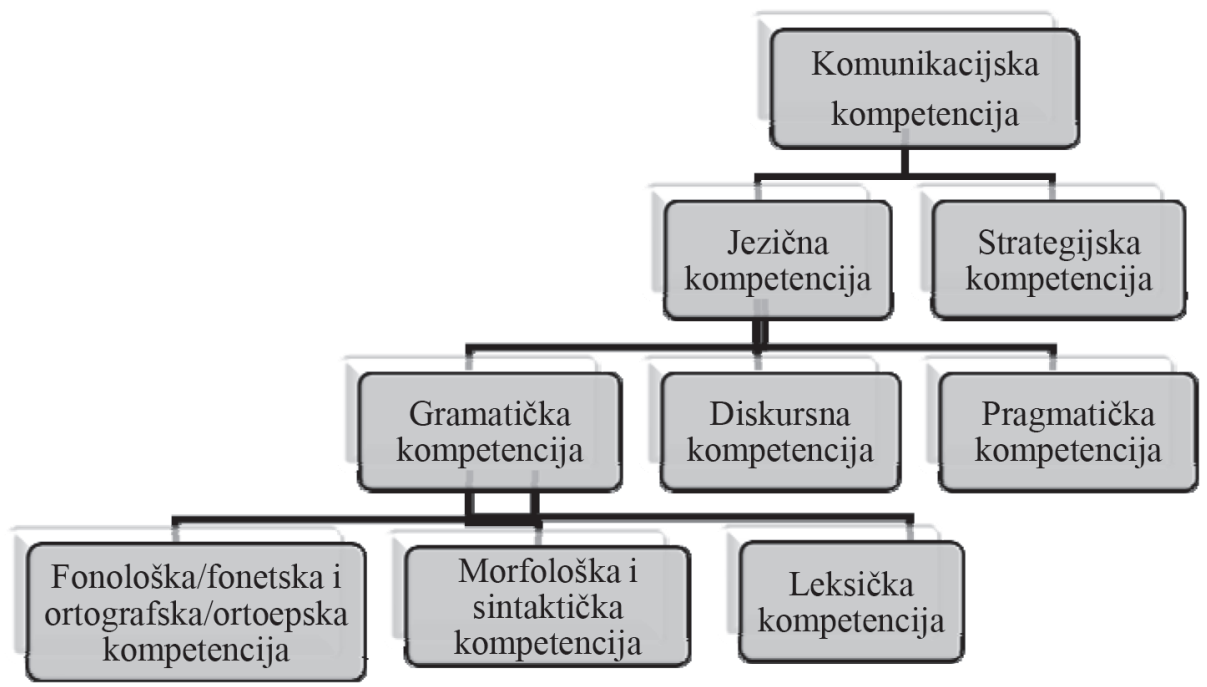

Slika 1. Struktura komunikacijske kompetencije

(Izrada autorice prema Pavičić Takač i Bagarić Medve, 2013)

\subsection{Odnos izmedu fonološke kompetencije i izgovornih odstupanja}

Iako se mnoga djela koja tematiziraju jezičnu kompetenciju kao fenomen i raščlanjuju je na sastavnice (usp. Pavičić Takač i Bagarić Medve, 2013; 
ZEROJ, 2005) ne koriste terminom „izgovorna kompetencija“, jasno je da o njoj možemo govoriti kada se ovladanost sastavnicama fonološke i ortoepske kompetencije manifestira u govornoj produkciji i govornoj interakciji, ${ }^{3}$ da se poslužimo terminima kojima se koristi rešetka samoprocjene ZEROJ-a (ZEROJ, 2005: 26). Ona definira zajedničke referentne razine komunikacijske kompetencije na stranom jeziku trima kategorijama - primanjem, interakcijom i produkcijom - te šest potkategorija - primanjem slušanjem, primanjem čitanjem, govornom i pisanom interakcijom te govornom i pisanom proizvodnjom.

O izgovornoj kompetenciji govore opisni okviri referentnih razina za hrvatski jezik, koji su zasada dostupni za referentne razine A2, B1 i B2. U njima se kao sastavnice te kompetencije opisuju ovladanost glasničkim repertoarom, asimilacijama, intonacijom i naglascima, a navedena su i odstupanja koja se toleriraju na pojedinoj razini (usp. Banković-Mandić, 2013; 2017). Na razini A2 govornik je potpuno ovladao slovima hrvatske abecede, ne dopuštaju se dakle odstupanja kojima je izvor u pismu (odnosno pogrešnom čitanju), dok su povremena fonološka odstupanja dopuštena (ali ih je važno korigirati jer ometaju razumijevanje poruke). Fonetska su odstupanja česta i toleriraju se jer ne narušavaju komunikaciju; govornik na razini A2 ima česta odstupanja vezana uz neasimiliranje glasova, ali razumije asimiliran (povezan) govor ako mu je vokabular poznat; dopuštaju se odstupanja u ostvarenju intonacijskih jezgara (vezano uz intonacijsku strukturu rečenice); te može odstupati u tonu i (ne)prelaženju naglaska na proklitiku, ali ne i u mjestu naglaska (Banković-Mandić, 2017: 200-208).

Veza je između kvantitete i naravi izgovornih odstupanja i jezične kompetencije samorazumljiva. Pretpostavka da će uslijed kvalitetnijeg izgovora inojezični govornici moći kompetentnije komunicirati na ciljanom jeziku potvrđena je mnogim istraživanjima, i to ne samo zato što određena odstupanja mogu uzrokovati prekid u komunikaciji (nerazumijevanje) nego i zato što jak strani akcent svraća pozornost $s$ referencijalne strane iskaza i usmjerava ga na formu iskaza, odnosno govornika. Ispravnim se realizacijama glasova, naime, smatraju one u kojima izvorni govornici ne primjećuju odstupanja (Desnica-Žerjavić, 2000), dok na nižim stupnjevima ovladanosti jezikom treba težiti prihvatljivomu izgovoru, a ne nužno izgovoru izvornoga govornika (Banković-Mandić, 2013). Kako bi se postigao prihvatljiv izgovor, jasno je da je potreban sustavan pristup izgovornim odstupanjima i da nastavnik svakako treba posvetiti pozornost njihovu otklanjanju. Sustavno se izgovornim odstupanjima može pristupiti ponajprije njihovim opisom,

\footnotetext{
${ }^{3}$ Umjesto termina "govorna produkcija“ i "govorna interakcija" opisni okviri referentnih razina za hrvatski jezik koriste se terminima "usmena proizvodnja (govor)" i "govorno međudjelovanje“ (usp. Nazalević Čučević, 2013).
} 
analizom i klasifikacijom, koji su osnova za odlučivanje o daljnjim koracima u procesu njihova otklanjanja.

Ponuđena je klasifikacija izrađena na temelju odstupanja uočenih $\mathrm{u}$ usmenoj proizvodnji i govornom međudjelovanju petero inojezičnih govornika u ranoj fazi formalnoga učenja hrvatskoga. Primjeri koji se navode u radu nastali su kao dio usmenog ispita nakon 30 sati (četiri učenika), odnosno 45 sati (jedan učenik) formalnog učenja hrvatskoga, a snimljeni su diktafonom. Učenici su čitali nizove izoliranih riječi koje su im trebale biti poznate, odnosno s kojima su se susreli na nastavi ili u izvannastavnom kontekstu, a također su uprizorili kratak dijalog u skladu sa svojom razinom ovladanosti jezikom.

Iako je riječ o ograničenom uzorku (dvama govornicima J1 je španjolski, dvjema govornicama J1 je gruzijski, a jednomu govorniku J1 je turski jezik), smatramo da to nije ograničavajuća okolnost s obzirom na to da ovaj rad ne pokušava dati iscrpan popis svih mogućih konkretnih izgovornih odstupanja. Naprotiv, pokušava dati klasifikaciju izgovornih odstupanja $\mathrm{u}$ koju se mogu uklopiti različite pojave i koja je univerzalno primjenjiva na hrvatski izgovor inojezičnih govornika neovisno o polaznim jezicima učenika. Osim toga, polazni jezici ispitanika na temelju čijih je izgovornih odstupanja izrađena ova klasifikacija relativno dobro predstavljaju jezičnu raznolikost svijeta s obzirom na to da pripadaju trima genetski različitim jezičnim porodicama - španjolski je jezik indoeuropski, gruzijski pripada kartvelskoj (južnokavkaskoj) jezičnoj porodici, a turski turkijskoj - s tipološki raznolikim fonološkim sustavima. Za svjetske jezike i jezike geografski i kulturološki bliske hrvatskomu postoje brojna kontrastivnolingvistička i glotodidaktička istraživanja njihova sučelja s hrvatskim u međujeziku inojezičnih govornika. To je slučaj sa španjolskim i turskim, dok hrvatski i gruzijski u domaćoj literaturi još nisu bili kontrastirani.

\section{PREGLED DOSADAŠNJIH ISTRAŽIVANJA IZGOVORNIH ODSTUPANJA U OVLADAVANJU J2}

Prvi su se pokušaji klasifikacije izgovornih odstupanja u ovladavanju inim jezikom javili još sredinom prošlog stoljeća u okviru tada relativno novog teorijskog okvira kontrastivne lingvistike (usp. Moulton, 1962), a bavili su se ponajprije pokušajima davanja odgovora na pitanje zašto se određene izgovorne "greške“ javljaju. Ti su dakle pokušaji polazili od pretpostavke da je za uspješno otklanjanje (tj. „ispravljanje“) "grešaka“ potrebno poznavati njihovu etiologiju, koja se ponajprije nalazi u međuodnosu između fonoloških sustava dvaju jezika - polaznog (,materinskog“) i ciljanog (,,stranog“) jezika učenika.

Moulton (1962) je ponudio klasifikaciju izgovornih "grešaka“ na fonemske, koje se odnose primarno na greške supstitucije (zamjene) 
nepoznatih fonema iz ciljanog jezika poznatim fonemima iz polaznog jezika i koje proizvode „riječ potpuno drugačiju od one koju se namjeravalo izgovoriti“, i fonetske, koje se odnose na prenošenje fonetskih navika iz polaznog jezika i rezultiraju upotrebom „pogrešnog fona“. Kod fonetskih je grešaka učenika inog jezika mnogo teže uvjeriti u nužnost ispravnog artikuliranja ciljanoga glasa (jer nema izravnih reperkusija na razumljivost ciljanog iskaza) (Moulton, 1962: 101).

Pitanje o dosezima i mogućnostima primjene kontrastivnih proučavanja grešaka stranih govornika na fonetskoj razini, odnosno razini izgovora u domaćoj je literaturi N. Desnica-Žerjavić postavila još krajem 1990-ih. Naime, kontrastivna se analiza „zadržala na fonologiji bez provjere svojih hipoteza na razini govornih realizacija", iako analiza interferencija između polaznog i ciljanog fonološkog sustava objašnjava mnoge procese do kojih dolazi pri njihovu susretu (Desnica-Žerjavić, 1998a: 38). Polazeći od analize grešaka kao pristupa koji je usmjeren na izvedbu govornika te od svjesnosti da je fonetska razina međujezika najneuhvatljivija i zbog toga najsloženija za analizu, ta je autorica ponudila i najiscrpniju klasifikaciju izgovornih grešaka u domaćoj literaturi (Desnica-Žerjavić, 1998a; 1998b; 2006). Greške izgovora autorica naziva "fonetskim greškama“, a podijelila ih je s obzirom na distinktivnost, sustavnost, interlingvalnost/intralingvalnost, učestalost, persistenciju, perceptibilnost, globalnost/lokalnost, izvor (zvuk/grafija) i stabilnost smjera otklona (Desnica-Žerjavić, 1998a; 1998b). Predloženu klasifikaciju izgovornih odstupanja autorica je upotrijebila $u$ analizi sustava grešaka hrvatskih govornika na naprednijim razinama francuskoga, tj. studenata i profesora francuskoga te govornika koji su francuski jezik među ostalim i spontano usvajali živeći u frankofonim zemljama. Elementi te klasifikacije, izrađene na temelju korpusa čitanja teksta na francuskome inojezičnih govornika na vrlo visokom stupnju ovladanosti jezikom, mogu biti korisni u razumijevanju klasifikacije koja se ovdje predlaže. Pritom valja spomenuti da je, za razliku od spomenute studije i klasifikacije koja se tamo donosi, cilj ovdje predložene klasifikacije da posluži ponajprije u svrhu poučavanja inojezičnog hrvatskog na početnim stupnjevima.

Kod N. Desnice-Žerjavić (1998a; 1998b) kriterij distinktivnosti odnosi se na to da se greške mogu javljati na distinktivnim i na redundantnim obilježjima glasova, odnosno distinktivne su greške one koje uzrokuju krivu identifikaciju glasova. Podjela grešaka prema sustavnosti na ",sistematske“ i „nesistematske“, odnosno greške kompetencije (prave greške) i greške performancije (lapsusi), može biti korisna nastavniku u odlučivanju o tome otklanjanju kojih grešaka treba posvetiti pozornost. Podjela prema interlingvalnosti/intralingvalnosti jest podjela na greške koje izvorni govornici ne bi nikada napravili odnosno one koje često prave, a u novijoj se literaturi potonje greške nazivaju „izvornim odstupanjima“ (usp. 
Gulešić-Machata i Udier, 2008). U ovdje se predloženoj klasifikaciji izvorna odstupanja, odnosno interlingvalne greške tretiraju kao odstupanja kojima na početnoj razini učenja hrvatskoga ne treba posvećivati osobitu pozornost $\mathrm{s}$ obzirom na to da ona ne uzrokuju teškoće u komunikaciji s izvornim govornicima. ${ }^{4}$ Dijeliti greške prema učestalosti ima smisla kada postoje uvjeti za provođenje kvantitativnih istraživanja i rangiranje s obzirom na broj pojavljivanja (Desnica-Žerjavić, 1998a: 40), dok je u situacijama poučavanja inojezičnomu izgovoru u kontekstu jezičnih vježbi realno očekivati da se takva podjela zasniva na impresijama (intuiciji i iskustvu) nastavnika, što ne znači nužno da od takvih zapažanja nastavnik ne bi dobio korisne informacije. Perceptibilnošću grešaka, odnosno stupnjem neugodnosti njihovih učinaka na sugovornika (Desnica-Žerjavić, 1998a: 41) ovaj se rad ne bavi, no o tom problemu postoji velik broj sociofonetskih istraživanja (usp. BankovićMandić, 2012; 2018; Desnica-Žerjavić, 2000; Šafarić, Ćalušić i Mildner, 2006). Podjela grešaka prema tvrdokornosti, odnosno redoslijed ovladavanja pojedinim sastavnicama glasovnog sustava ima smisla na višim stupnjevima učenja, ali impresije o toj dimenziji izgovornih odstupanja mogu pomoći nastavniku u odabiru redoslijeda uklanjanja pojedinih uočenih odstupanja, kao i u vrednovanju učeničkih govornih ostvarenja. Podjela na globalne i lokalne greške „u fonetici“ (proučavanju izgovornih odstupanja, op. a.) svodi se na razliku između "prozodijskih" i ,fonematskih grešaka“, odnosno "globalnih“ i „lokalnih“. Globalne su greške one koje se protežu na duže segmente govora ili greške na prozodijskim obilježjima (intonacija, ritam, tempo, stanke), dok se lokalne greške događaju na pojedinim glasovima. Za klasifikaciju predloženu u ovom radu također je vrlo korisna podjela grešaka prema izvoru (zvuk/grafija) jer omogućava bolje razumijevanje odstupanja koja su nazvana „ortoepskima“. Posljednja podjela, ona prema postojanosti smjera otklona, odnosi se na stalnost ili promjenjivost izgovornog odstupanja na istom glasu kod istoga govornika, a donosi informaciju o stadiju i smjeru usvajanja novog fonetskog sustava (Desnica-Žerjavić, 1998a: 41), te je također korisnija na višim stupnjevima učenja jezika. Među navedenim kategorijama kao one koje mogu biti primjenjive u početnim stadijima učenja hrvatskoga i korisne nastavnicima koji nemaju formalnog fonetskog obrazovanja (koji nisu fonetičari po temeljnoj struci) smatramo kriterij podjele po distinktivnosti, sustavnosti, interlingvalnosti/intralingvalnosti, globalnosti/lokalnosti i prema izvoru.

Za razliku od kontrastivne analize, koja je usporedbom polaznog i ciljanog glasovnog sustava nastojala predvidjeti "greške“ koje će se pojaviti,

\footnotetext{
${ }^{4}$ Primjer je izvornog odstupanja nerazlikovanje između postalveolarnih $(\check{c}, d \check{z})$ i alveopalatalnih afrikata $(c, d)$ u govoru mnogih izvornih govornika hrvatskoga, stoga se u ovom radu zastupa stav da se u poučavanju hrvatskoga kao J2, barem na početnim razinama učenja, ne treba inzistirati na toj distinkciji.
} 
te analize pogrešaka, koja je pak polazila od govornih ostvarenja inojezičnih govornika nastojeći tumačiti procese koji su doveli do tih pogrešaka, $u$ suvremenoj se literaturi, zahvaljujući psiholingvističkim istraživanjima, koja "greške" smatraju nezaobilaznom pojavom u procesu ovladavanja inim jezikom, koristi termin „odstupanja“ kako bi se izbjegle negativne konotacije vezane uz riječ „greška“/,pogreška“ (Banković-Mandić, 2013: 233).

U suvremenoj glotodidaktičkoj literaturi javljaju se mnogo jednostavnije klasifikacije učeničkih izgovornih odstupanja, kao što je podjela na segmentne i prozodijske „greške“ te „ostale probleme“ (usp. Derwing i Munro, 2015), dok se objašnjavanje zašto se pojedine greške javljaju izdvaja u posebna poglavlja. Osim što se time implicira da poznavanje razloga za pojavu odstupanja nije presudno za njihovo uklanjanje (usp. Derwing i Munro, 2015), pa ni za njihovu klasifikaciju, $u$ takvim se radovima kontrastivna analiza $\mathrm{i}$ analiza grešaka, u skladu s već spomenutom tendencijom, i eksplicitno odbacuju kao teorijska podloga nedostatna za tumačenje inojezičnih govornih pojava.

\section{KLASIFIKACIJA ODSTUPANJA}

Klasifikacija izgovornih odstupanja predložena u ovom radu ima pretenziju biti korisna u poučavanju na pripremnim početnim stupnjevima poučavanja inojezičnomu hrvatskomu. Izrađena je na temelju analize odstupanja petero učenika različitih polaznih jezika koji su primili 30 - 45 nastavnih sati pouke hrvatskomu kao drugom jeziku (tijekom učenja ujedno su i boravili u Hrvatskoj) ${ }^{5}$. S obzirom na broj sati primljene pouke, predložena klasifikacija može biti korisna u boljem razumijevanju izgovornih odstupanja i postavljanju strategije njihova otklanjanja na polovici odvijanja tečaja podrazine ovladanosti jezikom A1.1 prema ZEROJ-u.

U ovdje predloženu klasificiranju izgovornih odstupanja korištena su tri kriterija: kriterij izvora (je li izvor pojedinog odstupanja u govoru ili u pismu), kriterij razumljivosti (ometa li odstupanje razumijevanje ili ne) i kriterij globalnosti (javlja li se odstupanje na jednome segmentu, na suprasegmentnoj razini ili u kombinaciji dvaju ili više segmenata). Također se kao pomoćni kriteriji u tumačenju odstupanja i odlučivanju o ulaganju truda u njihovo otklanjanje mogu koristiti i kriteriji sustavnosti, učestalosti, perceptibilnosti i izvornosti (usp. Desnica-Žerjavić, 1998a; 1998b). U ovome je radu također zastupljeno stajalište da je nastavnikovo barem površno i vrlo bazično poznavanje polaznih jezika učenika (njihovih fonoloških, fonetskih i

\footnotetext{
${ }_{5}^{5}$ Temeljni elementi klasifikacije izgovornih odstupanja razrađene u ovom radu izneseni su u neobjavljenom izlaganju Fonološka i fonetska odstupanja govornika španjolskog, turskog i gruzijskog u početnom učenju hrvatskoga, održanom 13. srpnja 2019. na 12. Stručnom i znanstvenom savjetovanju za lektore hrvatskoga kao inoga jezika (SIH), te su korišteni u izlaganju Ispravljati ili ne? - razumljivost govorne proizvodnje učenika hrvatskoga kao inog jezika, održanom 15. studenoga 2019. na 7. međunarodnom znanstvenom skupu Hrvatski kao drugi i strani jezik (HIDIS).
} 
grafijskih sustava) u kontekstu tematike ovog rada osobito korisna okolnost (kao uostalom i u poučavanju ostalih jezičnih razina) jer pomaže nastavniku da bolje razumije kako učenici percipiraju novi jezik. ${ }^{6}$

\subsection{Ortoepska odstupanja}

Ortoepskim su nazvana ona odstupanja koja se javljaju zbog nedovoljne ovladanosti sastavnicama ortografske kompetencije, odnosno grafijskim sustavom kojim se bilježi ciljani jezik. Nepoznavanje ili nedovoljna automatiziranost interpretacije grafema ciljanog jezika očituje se $u$ pogrešnom izgovoru ciljanih segmenata pri čitanju riječi koje učeniku nisu otprije poznate i koje ne predstavljaju dio aktivnog leksika učenika. Također, ortoepska se odstupanja mogu javiti i u govornoj proizvodnji i govornom međudjelovanju kada se učenik koristi riječima čiji je lik susreo samo u pismu. Zajedničko je obama tipovima ortoepskih odstupanja (u čitanju i u govoru) to da im je izvor u pismu. Ortoepska se izgovorna odstupanja javljaju na početnim razinama učenja J2, a već na razini A2 ne bi se više smjela javljati (usp. Banković-Mandić, 2017). Važno je napomenuti da se pojava tog tipa odstupanja predviđa $u$ onih učenika koji novim jezikom ovladavaju i posredstvom pisma, odnosno neće se javiti u učenika koji su analfabeti i u kojih se ovladavanje novim jezikom odvija isključivo govorom. U tablici 1 navedeni su neki primjeri takvih odstupanja, ${ }^{7}$ zabilježeni s pomoću grafijskog sustava Međunarodne fonetske abecede (Śkarić, 2009).

Tablica 1. Primjeri ortoepskih odstupanja na početnoj razini učenja hrvatskoga kao J2

\begin{tabular}{|c|c|}
\hline $\begin{array}{c}\text { Ciljano } \\
\text { hrvatsko slovo }\end{array}$ & Izgovor \\
\hline$<\mathrm{c}>$ & 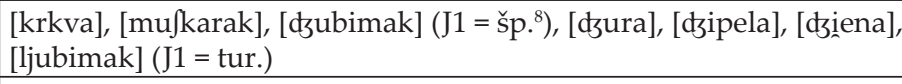 \\
\hline$<\mathrm{h}>$ & [mua], [ora], [vr] (J1 = šp.), [ora] (J1 = tur.) \\
\hline$<\mathrm{d} \check{z}>$ & [menaczer] (J1 = šp.; tur.), [dzezva], [udzbenik] ${ }^{9}(\mathrm{~J} 1$ = gruz.) \\
\hline$<\mathrm{g}>$ & [xenetika] (J1 = šp.) \\
\hline
\end{tabular}

\footnotetext{
${ }^{6}$ Negativna je strana nastavnikova poznavanja polaznih jezika učenika u tome što, kako napominje anonimni recenzent, korištenje obaju jezika (polaznog i ciljanog) na satu povećava mogućnost za interferenciju.

${ }^{7}$ Ciljane su riječi crkva, muškarac, ljubimac, cura, cipela, cijena, muha, orah, vrh, menadžer, džezva, udžbenik, genetika.

${ }^{8}$ U radu su korišteni oblici kratica glotonima (gruz. - gruzijski, šp. - španjolski, tur. - turski) predloženi na Hrvatskom jezičnom portalu (http://hjp.znanje.hr/?show=kratice_jezici).

${ }^{9}$ Radi jednostavnosti u fonetskom se prikazu hrvatskih slivenika ne koriste tilde (luk ispod obaju glasova), ali je razlika između slivenika i neslivenog izgovora predstavljena uporabom dvaju različitih slova (d子 : dz).
} 
Umjesto termina „ortografska odstupanja“, koji asocira na odstupanja u pisanju, odlučenoje koristiti se pridjevom „,ortoepski“ , što je rješenje koje nudi ZEROJ (2005). Prema ZEROJ-u, da bi korisnici J2 mogli ispravno pročitati naglas „neki pripremljeni tekst, ili u govoru koristiti riječi s kojima su se susreli samo u pisanom obliku, moraju biti sposobni ispravno ih pročitati na temelju pisanog predloška“. Ortoepska kompetencija prema ZEROJ-u (2005: 120-121) uključuje i neke sposobnosti koje su svojstvene učenicima na višim stupnjevima ovladanosti jezikom (npr., poznavanje sustava za bilježenje izgovora; implikacije pisanih oblika, posebno interpunkcija, za označavanje ritma i intonacije te sposobnost rješavanja nejasnoća s pomoću konteksta), među kojima na razini učenja o kojoj je ovdje riječ ima smisla služiti se oznakama za bilježenje mjesta naglaska (crticom ispod naglašenoga vokala), što je svakako preporučljivo na razini A2 (usp. Banković-Mandić, 2017: 199 i 207).

\subsection{Fonološka odstupanja}

Kao glavni je kriterij za razlikovanje između fonoloških i fonetskih odstupanja, po uzoru na radove slične tematike, uzet kriterij razumljivosti. Tako se kao fonološka odstupanja klasificiraju ona odstupanja koja ometaju komunikaciju, a fonetskima se smatraju odstupanja koja osobu identificiraju kao neizvornog govornika (Banković-Mandić, 2012). Dodatni je kriterij za definiranje fonoloških odstupanja onaj prema kojemu su to odstupanja („greške“) na distinktivnim obilježjima glasova, dok je kod fonetskih odstupanja riječ o "greškama“ na redundantnim obilježjima (usp. DesnicaŽerjavić, 1998a; 2006). Taj je dodatni kriterij potrebno uvesti jer ponekad komunikacijski kontekst i sama glasovna okolina ciljanog segmenta na kojem se javlja odstupanje osiguravaju razumljivost. Ovisno o tim okolnostima, izgovor 'Zagreb', 'Zadar' i 'zima' kao [Sagreb], [Sadar], [sima] možda neće stvoriti komunikacijske poteškoće, ali to ne mijenja činjenicu da je opreka po zvučnosti ono što razlikuje hrvatske nadzubne tjesnačnike /s/i /z/ te da treba nastojati da učenici ovladaju tom oprekom.

U ovom se radu kao prototipna fonološka odstupanja poimaju odstupanja $\mathrm{u}$ izgovoru vokala i konsonanata kojima je uzrok interferencija, odnosno međudjelovanje između fonoloških sustava polaznoga i ciljanog jezika, a čija je posljedica otežana razumljivost ili nerazumljivost govorne produkcije na hrvatskom jeziku. Prema Weinreichu, interferencija između dvaju fonoloških sustava može rezultirati različitim procesima: ukidanjem opozicija između dvaju glasova inog jezika i njihovom zamjenom jednim glasom polaznog sustava (neutralizacijom opozicija); uvođenjem opozicija iz polaznog jezika u ciljani jezik koje taj jezik ne poznaje; reinterpretacijom razlika, odnosno shvaćanjem redundantnih obilježja kao relevantnih; te supstitucijom fonema koji su u dvama jezicima identično definirani, ali se razlikuju u 
fonetskoj realizaciji (Desnica-Žerjavić, 1998a: 23-24.) Prva tri Weinreichova tipa interferencije kod Jakobsona se nazivaju "defonemizacijom", „fonemizacijom“ i „transfonemizacijom“ (Desnica-Žerjavić, 1998a: 24), a oni jesu mehanizmi svojstveni nastanku fonoloških odstupanja. Posljednji tip, supstitucija, koji rezultira različitom fonetskom realizacijom glasova koji se smatraju podudarnima u dvama sustavima, oblikuje područje fonetskih odstupanja (Desnica-Žerjavić, 1998a).

Kada je riječ o definiranju odstupanja („grešaka“) u govoru, nezaobilazni su radovi akademika Petra Guberine. Prema Guberini (2010), izgovorne pogreške koje se javljaju pri ovladavanju novim jezikom čine "sustav grešaka“ ili „,sustav zamjena“, koji se rađa iz sukoba dvaju glasovnih sustava - materinskog i stranog. Sustav grešaka određujuće je obilježje međujezika, koji je na počecima ovladavanja novim jezikom više pod utjecajem polaznog jezika, a kasnije slabi proporcionalno sa stupnjem ovladanosti ciljanim jezikom. Drugim riječima, glavni je razlog utjecaja glasova polaznog jezika na realizaciju glasova ciljanog jezika u govoru pojedinca „mehanizam fonološkog slušanja prema kojem se glasovi stranog jezika percipiraju kroz 'fonološko sito' materinskog jezika" (Horga, 2014). Prema Guberininoj teoriji verbotonalnog sistema, dok govorimo, primjenjujemo skup postupaka koji se mogu opisati kao leksička i neleksička sredstva izražavanja. Leksička sredstva jesu leksički i gramatički (fonetika, morfologija, sintaksa) sustav, a neleksička sredstva izražavanja (ili „vrednote govornog jezika“) jesu, među ostalim, intonacija, ritam, intenzitet, napetost, pauza, rečenični tempo, mimika, geste, položaj i napetost tijela (Guberina, 1986). U skladu s podjelom na leksičke i neleksičke postupke koji se koriste $\mathrm{u}$ govoru, greške u ovladavanju stranim jezikom dijele se na segmentalne i suprasegmentalne, pri čemu su greške u ritmu i intonaciji (na suprasegmentalnoj razini) najizrazitije obilježje „stranog naglaska“. Fonološka bi odstupanja (greške u izgovoru suglasnika i samoglasnika) prema Guberininoj teoriji bila stvar "gramatičkog sustava", odnosno grešaka u korištenju leksičkih sredstava izražavanja.

Iako se točna etiologija i mehanizam nastanka pojedinog fonološkog odstupanja ne razmatraju u ovome radu, polazi se od pretpostavke da bi za uspješno identificiranje odstupanja kao fonološkog i učinkovit pristup njegovu otklanjanju bilo dobro poznavati, barem rudimentarno, polazni glasovni sustav učenika. Ako poznaje osnove fonologije, primjerice, španjolskoga, nastavnik će zapaziti da taj polazni glasovni sustav ne sadržava glasove usporedive s hrvatskima [z], [3] i [ts], pa će moći pretpostaviti da bi njihov izgovor mogao stvarati poteškoće.

Istraživanja fonoloških i fonetskih odstupanja učenika hrvatskoga kao drugog i stranog jezika kojima su prvi jezici kineski, engleski, njemački i španjolski ukazala su na to da svi govornici bez obzira na J1 imaju slična odstupanja, i to u mjestu naglaska i neslivenom izgovoru $l j$, dok druga 
odstupanja ovise o prvom jeziku učenika (Banković-Mandić, 2012). Ne čudi što većina učenika hrvatskoga kao inog jezika ima poteškoća s izgovorom lj s obzirom na to da samo $4,4 \%$ svjetskih jezika ima taj glas. ${ }^{10} \mathrm{U}$ tablici u nastavku prikazana su neka fonološka odstupanja zabilježena tijekom usmenog ispita prigodnog uzorka učenika inojezičnog hrvatskog. ${ }^{11}$

Tablica 2. Primjeri fonoloških odstupanja na početnoj razini učenja hrvatskoga kao J2

\begin{tabular}{|c|c|}
\hline $\begin{array}{c}\text { Primjer fonološkog } \\
\text { odstupanja }\end{array}$ & Izgovor \\
\hline $\begin{array}{l}\text { obezvučenje zvučnih } \\
\text { suglasnika }\end{array}$ & [Sagreb], [Sadar], [sima], [tfisma], [ [aßa]/[zaßa] $(\mathrm{J} 1$ = šp. $)$ \\
\hline delateralizacija / $/$ / & $\begin{array}{l}\text { [dzubav]/[jubav], [dzubimak] (J1 = šp.), [ljubav], [ljubimac] }(\mathrm{J} 1=\text { tur.), } \\
\text { [ulje], [polje] (J1 = šp., tur., gruz.) }\end{array}$ \\
\hline nepalatalni izgovor /n/ & [niematfka], [niegov], [niezin] ( $\mathrm{J} 1=$ tur. $)$ \\
\hline promjene /ts/ & [ValenӨiie], [XerOegovina], [sipela] (J1 = šp.) \\
\hline
\end{tabular}

Kada je riječ o fonološkoj kompetenciji, razni priručnici kao najčešće sastavnice fonološke kompetencije ističu poznavanje glasova te njihovih artikulacijskih (alofoni, kombinatorne i slobodne varijante) i akustičkih svojstava (razlikovna obilježja), fonema, fonoloških opreka i minimalnih parova, raspodjele fonema, slogova i pravila o fonemskoj strukturi sloga, morfema i riječi, trajanja sloga, naglaska riječi te rečenične intonacije, naglaska, ritma i melodije. Kao sastavnice ortografske kompetencije ističu se, među ostalim, poznavanje upotrebe i kombiniranja slova u riječima. Sve te sastavnice učenici stranog jezika trebaju poznavati na razini primanja i proizvodnje (Pavičić Takač i Bagarić Medve, 2013: 115) te se njima koristiti u praksi.

\subsection{Fonetska odstupanja}

Kao što je već spomenuto, kao fonetska se odstupanja definiraju ona koja ne ometaju komunikaciju, ali identificiraju osobu kao neizvornog govornika. Ta je klasifikacija odstupanja važna jer ima reperkusije na odlučivanje o tome otklanjanju kojih odstupanja valja posvetiti pozornost - ako je odstupanje klasificirano kao fonološko, u pravilu bi trebalo nastojati da ga se otkloni, dok su fonetska odstupanja neizbježna i ne treba inzistirati na njihovu otklanjanju na samim počecima učenja jezika jer bi ono moglo obeshrabriti učenike i usporiti ih u stjecanju komunikacijske kompetencije. S druge strane, na višim stupnjevima učenja jezika važno je i potrebno da učenici usvoje i fonetska nerazlikovna obilježja stranog jezika (Desnica-Žerjavić, 1993).

\footnotetext{
${ }^{10} \mathrm{http}$ ://web.phonetik.uni-frankfurt.de/upsid_segment_freq.html

${ }^{11}$ Ciljane su riječi Zagreb, Zadar, zima, čizma, žaba, ljubav, ljubimac, ulje, polje, Njemačka, njegov, njezin, Valencije (G jd.), Hercegovina, cipela.
} 
U kontekstu nastavnih aktivnosti pri formalnom učenju J2 nastavnik se nalazi u poziciji stručnog procjenitelja izgovora, ${ }^{12}$ odnosno on je taj koji prosuđuje je li pojedino odstupanje fonološko ili fonetsko. Međutim, on ponekad može i pogriješiti u prosudbi o tome hoće li govorni iskaz biti razumljiv izvornomu govorniku ili neće. Budući da je za distinkciju između fonoloških i fonetskih odstupanja temeljni kriterij razumljivosti, a hoće li iskaz biti razumljiv, ovisi i o sugovorniku, postavlja se pitanje može li nastavnik, bez obzira na svoju stručnost, predvidjeti sve poteškoće do kojih bi u sporazumijevanju s izvornim govornicima moglo doći. Zbog toga treba istaknuti da je predloženi popis fonetskih odstupanja izrađen na temelju procjene nastavnika o tome koja odstupanja neće uzrokovati probleme $\mathrm{u}$ komunikaciji, dok bi za realniju ocjenu trebalo provjeriti razumiju li izvorni govornici ciljane iskaze. Nastavnik se u svojoj procjeni može poslužiti i dodatnim kriterijem definiranja fonetskih odstupanja, onim prema kojemu su to odstupanja na redundantnim obilježjima. Budući da u hrvatskome ne postoji opreka između nepalataliziranih i palataliziranih konsonanata, kao u ruskome, niti opreka između nadzubnog treptajnika ([r]) i nadzubnog dotačnika ([r]), kao u španjolskome, primjeri koji su navedeni u tablici 3 mogu se klasificirati kao fonetska odstupanja. ${ }^{13}$

Tablica 3. Primjeri fonetskih odstupanja na početnoj razini učenja hrvatskoga kao J2

\begin{tabular}{|c|c|}
\hline $\begin{array}{c}\text { Primjer fonetskog } \\
\text { odstupanja }\end{array}$ & Izgovor \\
\hline omekšan izgovor /1/ & [galeb], [ulitsa] (J1 = gruz., tur., šp.) \\
\hline obezvučenje na kraju riječi & [Zagrep], [brot], [sl'etc] (J1 = gruz., tur.) \\
\hline [r] umjesto [r] & [robot] $(\mathrm{J} 1=$ šp. $)$ \\
\hline palataliziranost & [dijetie], [dieveti $]^{14}$ (J1 = gruz., J2 = rus.) \\
\hline ejektivnost & [oblak'] (J1 = gruz.) \\
\hline $\begin{array}{l}\text { laringalnost/ } \\
\text { glotalnost }\end{array}$ & [vrh], [smieh] $(\mathrm{J} 1$ = gruz. $)$ \\
\hline
\end{tabular}

${ }_{12}$ Kao stručni se procjenitelji razumijevaju „oni procjenitelji koji se bave poučavanjem i istraživanjem hrvatskoga kao stranog jezika“ (Banković-Mandić, 2019). Istina je da nisu svi nastavnici hrvatskoga kao J2 po struci i fonetičari (koji bi bili najstručniji za procjenu izgovora), ali oni su (nastavnici) vrlo često jedina lingvistički obrazovana osoba koja je u prilici baviti se izgovorom svojih učenika/studenata (s obzirom na to da ne uključuju svi programi učenja hrvatskoga kao J2 izgovorne/fonetske vježbe pod paskom fonetičara).

${ }^{13}$ Ciljane su riječi galeb, ulica, Zagreb, brod, sled, robot, dijete, devet, oblak, vrh, smijeh.

${ }^{14} \mathrm{U}$ pisanju dijakritika korišten je sustav bilježenja Međunarodne fonetske abecede (https://www.internationalphoneticassociation.org/content/ipa-diacritics; https://www.internationalphoneticalphabet.org/html-ipa-keyboard-v1/keyboard/). 


\subsection{Koartikulacijska odstupanja ${ }^{15}$}

Kao koartikulacijska se odstupanja u ovoj klasifikaciji razumijevaju ona koja se javljaju kada je učenik u stanju realizirati pojedinačne segmente ciljanog jezika, ali ne i neke njihove kombinacije. Koartikulacija se u najširem smislu riječi može definirati kao artikulacijske prilagodbe koje se javljaju kao rezultat utjecaja segmenata na susjedne segmente (Volenec, 2015). Jedna od definicija iz područja artikulacijske fonetike opisuje tu pojavu kao utjecaj dvaju ili više izgovornih segmenata na govorni trakt, odnosno preklapanje pokreta artikulatora u vremenu i njihov međusobni utjecaj (Horga i Liker, 2016). Ta pojava utječe na različitu realizaciju glasnika ovisno o glasničkoj okolini, ali se fonemski lik glasnika pritom ne mijenja, odnosno tipični govornik nema problema s njegovom percepcijom (Horga i Liker, 2016: 290).

Koartikulacijska su odstupanja dakle uvjetovana raspodjelom fonema i strukturom sloga, a kao njihov prototipan primjer u govornom materijalu na temelju kojega je izrađena ova klasifikacija javljaju se odstupanja povezana s hrvatskim [r] („,slogotvorno $\left.r^{\prime \prime}\right)$. Naime, iako su svi učenici na temelju čijih je snimaka hrvatskoga izgovora ponuđena ova klasifikacija bili uspješni $u$ izgovoru hrvatskoga [r] u ne-slogotvornoj poziciji, kada bi se taj glas našao u slogotvornoj funkciji i u blizini tjesnačnika [ts], nastupale bi poteškoće. Tada bi umjesto nadzubnog treptajnika (što je u hrvatskome prototipni ostvaraj [r]) ostvarivali nadzubni približnik [I] ili bi pak umjesto slivenika [ts] ostvarivali tjesnačnik [s]. Ostala primijećena odstupanja koja su se javljala kao posljedica djelovanja glasovne okoline na ciljani segment prikazana su shematski u tablici $4 .{ }^{16}$

Tablica 4. Primjeri koartikulacijskih odstupanja na početnoj razini učenja hrvatskoga kao J2

\begin{tabular}{|c|c|}
\hline $\begin{array}{c}\text { Primjer koartikulacijskog } \\
\text { odstupanja }\end{array}$ & Izgovor \\
\hline promjene r r & [c.sn] (J1 = šp.), [srkva], [srrn] (J1 = tur.), [crn] i [c.n] $(\mathrm{J} 1$ = gruz.) \\
\hline sufiks $-(a)_{c}$ & 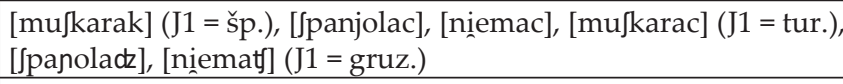 \\
\hline inicijalno $j-$ & [dzabuka], [dzedan] (J1 = šp.) \\
\hline skupina /xt/ & [tsieti] (J1 = šp.), [xitieti] (J1 = tur.) \\
\hline palatalizacija na daljinu & [vozat], [tizma] (J1 = gruz.) \\
\hline
\end{tabular}

\footnotetext{
${ }^{15}$ Zahvaljujemo dr. sc. Ivančici Banković-Mandić i profesoru Radovanu Lučiću, slušačima na 12. Stručnom i znanstvenom savjetovanju za lektore hrvatskoga kao inoga jezika (SIH), na pomoći u odabiru termina koji će odgovarati primijećenomu tipu odstupanja.

${ }^{16}$ Ciljane su riječi crn, crkva, muškarac, Španjolac, Nijemac, jabuka, jedan, htjeti, vozač, čizma.
} 


\subsection{Naglasna odstupanja}

Za razinu A2, koja se postiže nakon 140 sati učenja, dopuštena su odstupanja $\mathrm{u}$ tonu i (ne)prelaženju naglaska na proklitiku, ali ne i u mjestu naglaska (Banković-Mandić 2017: 200-208). Naglasna su odstupanja na početnoj razini učenja hrvatskoga, o kojoj je ovdje riječ, očekivana i česta, a stajalište s kojeg se polazi u ovome radu jest da ih je potrebno otklanjati samo kada uzrokuju poteškoće u sporazumijevanju. U prvom i trećem dolje navedenom primjeru riječ je o odstupanju u naglasnome mjestu, a u primjeru izgovora htjeti riječ je i o umetanju vokala između dvaju konsonanata u problematičnom pristupu slogu, pri čemu je umetnuti samoglasnik postao nositeljem naglaska.

Tablica 5. Primjeri naglasnih odstupanja na početnoj razini učenja hrvatskoga kao

J2 koja uzrokuju poteškoće u sporazumijevanju

\begin{tabular}{|l|l|}
\hline \multicolumn{1}{|c|}{$\begin{array}{c}\text { Primjer naglasnog } \\
\text { odstupanja }\end{array}$} & \multicolumn{1}{c|}{ Izgovor } \\
\hline hódati & {$[$ xo'dati $](\mathrm{J} 1=$ tur. $),[$ xo' đati $](\mathrm{J} 1=$ šp. $)$} \\
\hline htjëti & {$\left[\mathrm{x}^{\prime}\right.$ otịeti $](\mathrm{J} 1=$ tur. $) ;\left[\mathrm{x}^{\prime}\right.$ itịeti $](\mathrm{J} 1=$ tur. $)$} \\
\hline đävao & {$[\mathrm{d}$ zav'ao $](\mathrm{J} 1=$ gruz. $)$} \\
\hline
\end{tabular}

\section{REPERKSUSIJE PREDLOŽENE KLASIFIKACIJE NA POUČAVANJE IZGOVORU HRVATSKOGA KAO J2 - REDOSLIJED I METODE OTKLANJANJA IZGOVORNIH ODSTUPANJA}

Iz dosad izloženog vidljivo je da je jedan od temeljnih kriterija koji su primijenjeni u klasificiranju kriterij razumijevanja, odnosno pitanje o tome uzrokuje li odstupanje probleme u komunikaciji ili ne. Klasifikacija odstupanja prema tomu kriteriju omogućuje odlučivanje o tome treba li nastojati da se odstupanje ukloni ciljanim naporima ili ne. Druga dva kriterija, kriterij izvora odstupanja, odnosno kriterij globalnosti, pomažu u odlučivanju o tome kojim redoslijedom treba uklanjati uočena odstupanja i kojim metodama. Kriteriji za klasifikaciju odstupanja shematski su prikazani u tablici 6.

Tablica 6. Klasifikacija izgovornih odstupanja prema kriterijima razumljivosti, izvora i globalnosti

\begin{tabular}{|l|c|c|c|c|}
\hline Odstupanje & Razumljivost & Izvor & Globalnost & Uklanjati \\
\hline ortoepsko & 0 & pismo & razina segmenta & DA \\
\hline fonološko & - & zvuk & razina segmenta & DA \\
\hline fonetsko & + & zvuk & razina segmenta & NE \\
\hline koartikulacijsko & 0 & zvuk & suprasegmentna razina & DA \\
\hline naglasno & 0 & zvuk & suprasegmentna razina & DA/NE \\
\hline
\end{tabular}


Osim što doprinosi usustavljivanju i boljemu razumijevanju izgovornih odstupanja koja se mogu očekivati na početnome stupnju učenja hrvatskoga, predložena klasifikacija pruža nastavniku okvir unutar kojega može pronaći smjernice za određivanje redoslijeda otklanjanja pojedinog tipa odstupanja i odabir odgovarajućih metoda poučavanja.

Doneseni model izgovornih odstupanja predlaže da se započne s uklanjanjem onih odstupanja koja su identificirana kao ortoepska, odnosno onih za koja se pretpostavlja da je njihov uzrok nedovoljna ovladanost grafijskim sustavom i ortografskim konvencijama ciljanog jezika. To nikako ne znači da je za dobar izgovor temelj grafija, nego su takva odstupanja najbanalnija i svojstvena upravo samim počecima učenja J2, zbog čega za njihovo uklanjanje nastavnik treba uložiti najmanje truda. Naime, susret $\mathrm{s}$ inim jezikom $\mathrm{u}$ formalnom kontekstu obično započinje upravo s poučavanjem grafijskomu sustavu ciljanog jezika. Uz pretpostavku da je primio zadovoljavajuću pouku, učenikov je zadatak usvojiti grafijska rješenja te ortografska pravila i zakonitosti ciljanoga jezika kako se u njegovoj govornoj proizvodnji ne bi javljala odstupanja pod utjecajem nedovoljne ovladanosti pismom. Također, zadatak je učenika uvježbati čitanje na inome jeziku i osigurati unos pisanog materijala na J2 dovoljan za automatizaciju procesa čitanja. Ortoepska se odstupanja osim u čitanju teksta na ciljanom jeziku mogu pojaviti i u govornoj proizvodnji i interakciji kada se inojezični govornik služi leksičkim jedinicama s kojima se susreo samo u pismu. Riječ je dakle o specifičnoj vrsti pogreške koja se javlja kada učenik jedini kontakt s novom riječi ostvaruje posredstvom pisma (ciljanu riječ nije imao priliku čuti na nastavi ili u izvannastavnom kontekstu), a nije još dobro ni ovladao grafijom ciljanog jezika. Primjer je takvog odstupanja izgovaranje hrvatske riječi 'muškarac' kao [mufkarak] - učenikov izgovor oblikovala je $\mathrm{u}$ ovom slučaju vizualna slika te riječi u pismu i njegovo tumačenje $<c>$ kao [k]. Stoga je važno poticati učenike da se u samostalnom radu što više služe audiomaterijalima te mogućnostima koje im pruža suvremena informacijskokomunikacijska tehnologija (primjerice, zvučnim materijalima koji dolaze uz najčešće korištene alate za strojno prevođenje) kako se u oblikovanju zvučne slike ciljane riječi ne bi previše oslanjali na pisani materijal. Iako se ističe da je za ovladavanje izgovorom presudna uloga nastavnika te da na samom početku učenicima nije dovoljan zvučni zapis (usp. Guberina, 2010), ipak smatramo da je korištenje zvučnih materijala korisno u otklanjanju upravo opisanog tipa odstupanja.

Za uklanjanje ostalih tipova odstupanja nastavnik će svakako morati uložiti mnogo više truda jer ona najčešće ne proizlaze iz nezainteresiranosti ili smanjene pozornosti učenika. Naime, fonološka kompetencija najteže je usvojiva sastavnica jezične kompetencije, a na visokim razinama poznavanja J2 upravo je strani naglasak ono što identificira osobu kao neizvornoga 
govornika. Dakle, pretpostavka je da će i fonološka, koartikulacijska, naglasna i fonetska odstupanja - tim redoslijedom - biti teže ukloniti nego ortoepska. Za uklanjanje nabrojanih odstupanja nastavniku na raspolaganju stoji niz metoda kojima se može služiti u organiziranju svojevrsnih govornih vježbi, oslanjajući se pritom na svoje fonetske kompetencije - grupno ponavljanje za nastavnikom ili ponavljanje nekog zvučnog zapisa, domaći zadaci čitanja teksta naglas, glasno čitanje fonetski težeg teksta te uvježbavanje pojedinih naglasnih modela s učenicima (Banković-Mandić, 2014).

Ako nastavnik ima priliku više se posvetiti poučavanju izgovoru, može se upustiti i u fonetsku korekciju izgovora prema Guberininoj verbotonalnoj metodi. Prema toj metodi, nastavnik najprije identificira odstupanje, nakon čega postavlja cilj (izgovor kojemu se teži) i priprema odgovarajuće materijale. Nikada se istovremeno ne ispravljaju dvije greške (izgovor dvaju glasova odjednom) niti se glasovi korigiraju izolirani. Postupci kojima je cilj ovladavanje pojedinim elementima (glasovima) bazirani su na cjelinama, zbog čega fonetska korekcija uvijek započinje rečenicom kako bi učenik usvojio ritam i intonaciju ciljanog jezika. Nakon što učenik korektno imitira intonaciju i ritam (globalnu strukturu, tj. suprasegmentalnu razinu), poboljšava se i segmentalna razina govora na stranom jeziku (izgovor pojedinih nepravilno izgovorenih glasova) (Galić, 2015). U svrhu korekcije izgovora koriste se i različite vježbe, kao što su ponavljanje logatoma (slogova bez značenja), pljeskanje u ritmu rečenice, ponavljanje melodije, udarci na mjestu rečeničnog naglaska i sl. Takav sintetički pristup uključuje u rad na glasovima sva dostupna pomagala - od jezičnih (prilagođeni materijal), akustičkih (modifikacija signala) do kinestetskih (uključuje i tijelo jer cijelo tijelo i sudjeluje u govoru).

Za uklanjanje fonoloških odstupanja osobito je korisno uvježbavanje izgovora minimalnih parova (štoje preporučljivo na visokoj razini poznavanja jezika jer je inače prilično zahtjevno), a za uklanjanje koartikulacijskih uvježbavanje izgovora ciljanog segmenta $u$ određenom glasovnom kontekstu. Primjerice, za uklanjanje koartikulacijskih odstupanja navedenih u ovom radu bilo bi potrebno osmisliti zadatke u kojima će se uvježbavati izgovor [r] uz slivenike, [ts] u finalnom položaju, [j] u inicijalnom te skupine [xt]. Pretpostavka je da učenici najprije trebaju osvijestiti pojedinačne foneme, kako bi uklonili fonološka odstupanja, a zatim i pojedine njihove kombinacije, kako bi uklonili koartikulacijska odstupanja. Naravno, kvantiteta i narav odstupanja različita je kod svakog pojedinog učenika, zato je idealno ako im se nastavnik može individualno prilagođavati kreiranjem nastavnog materijala i odabirom odgovarajućih metoda poučavanja.

Sljedeći korak na putu prema postizanju prihvatljivog izgovora jest uklanjanje naglasnih odstupanja, a na razini o kojoj je ovdje riječ ponajprije se treba fokusirati na uklanjanje odstupanja u mjestu naglaska. Pretpostavka 
je da će i naglasna odstupanja biti teže otkloniti zato što njihovo otklanjanje nije nešto što učenik može ostvariti bez oslanjanja na zvučni materijal ili na nastavnika kao modelskog govornika. Naime, hrvatski se naglasci ne bilježe u pismu, kao što je slučaj s nekim drugim europskim i svjetskim jezicima, ${ }^{17}$ a učenici se u samostalnome radu najčešće oslanjaju upravo na pisani nastavni materijal. Kako bi učenicima olakšao ovladavanje naglasnim mjestom $u$ hrvatskome, u materijalima koje sam priprema nastavnik se može poslužiti podcrtavanjem naglašenog sloga. Međutim, nisu svi materijali za učenje opremljeni takvim oznakama, zato je susret s ciljanim jezičnim oblikom na samoj nastavi, iz usta nastavnika, koji je izvorni govornik ciljanog jezika, često jedina prilika učenicima inojezičnoga hrvatskog da se susretnu s jezičnom jedinicom u govoru i čuju kako bi ju trebalo ispravno naglasiti. Naime, za razliku od nekih jezika u kojima je naglasno mjesto fiksirano ili postoje razmjerno jasna pravila $u$ određivanju mjesta naglaska, hrvatski pripada skupini jezika kod kojih je mjesto naglaska relativno nepredvidivo, odnosno jedino pravilo na koje se učenik može osloniti kada je riječ o naglašavanju hrvatskih riječi jest ono prema kojemu naglasak ne može biti na posljednjem slogu u riječi (ako taj slog nije ujedno i jedini). Zbog toga je važno da nastavnik potiče učenike da se u samostalnom radu služe i audiomaterijalima, koji se najčešće mogu nabaviti uz postojeće udžbenike i vježbenice za učenje hrvatskoga kao inog jezika. S obzirom na, među ostalim, i brojne prijepore i rasprave o tome kojemu bi naglasnomu sustavu hrvatskoga standarda trebalo poučavati inojezične govornike, teza je koju se zastupa u ovome radu da učenike hrvatskim naglascima treba poučavati, barem na početnoj razini, samo u onoj mjeri koja je potrebna da se izbjegnu odstupanja koja uzrokuju nerazumljivost govorne proizvodnje.

Posljednja na ljestvici prioriteta u otklanjanju jesu fonetska odstupanja. Naime, fonetska su odstupanja neizbježna pojava i na najvišim stupnjevima ovladavanja jezikom. Međutim, kao što je već ranije istaknuto, nastavnik treba biti oprezan $u$ procjenjivanju toga koja su odstupanja fonetska jer se može dogoditi da odstupanje koje je procijenjeno kao fonetsko zapravo ometa komunikaciju. Predloženi redoslijed otklanjanja pojedinih tipova izgovornih odstupanja shematski je prikazan na slici 2 .

\footnotetext{
${ }^{17}$ Jedan je od takvih europskih jezika španjolski, u kojemu se u pismu bilježi naglasno mjesto, pa poznavanje pravopisnih konvencija osigurava i ispravno naglašavanje u govoru. Zbog toga je razumljivo razočaranje španjolskih učenika hrvatskoga kada otkriju da naglasno mjesto (kao ni ostale akcenatske osobine izgovora) u hrvatskome nije predvidivo pismom, odnosno da dijakritički znakovi u hrvatskome služe u druge svrhe.
} 


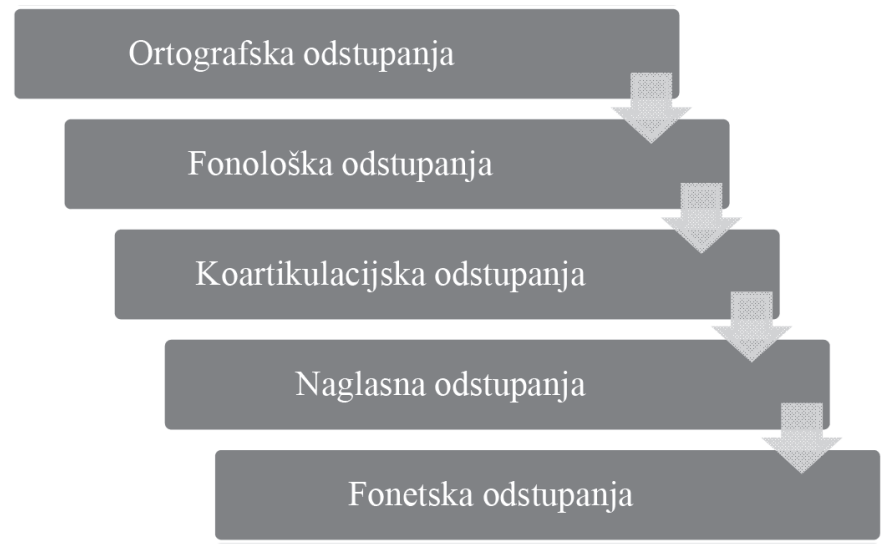

Slika 2. Redoslijed otklanjanja izgovornih odstupanja na početnoj razini učenja hrvatskoga

\section{ZAKLJUČAK}

Suvremeni pristupi inojezičnomu poučavanju sve su više kompetencijski, odnosno usmjereni su na to da učenik inog jezika stekne odgovarajuću komunikacijsku kompetenciju. Pri tome se misli na sposobnost učenika da kompetentno komunicira na ciljanom jeziku, a s takvog se polazišta može učiniti da je posvećivanje pozornosti izgovornoj kompetenciji suvišno. Međutim, ako se izgovorna kompetencija definira kao manifestiranje fonološke, ortoepske i fonetske kompetencije u usmenoj proizvodnji i govornoj interakciji, može se zaključiti da je ona važna sastavnica gramatičke i jezične te u konačnici i same komunikacijske kompetencije. Drugim riječima, nedovoljna ovladanost sastavnicama izgovorne kompetencije može imati reperkusije na učinkovitost komuniciranja na ciljanom jeziku. Imajući tu činjenicu na umu, nastavnik bi trebao raditi na tome da učenik ovlada izgovorom $u$ mjeri u kojoj on neće ometati komuniciranje s drugim govornicima, ponajprije izvornim. Na višim razinama učenja tu minimalnu razinu svakako bi bilo dobro i nadići s obzirom na to da je, kako ističe anonimni recenzent, a što je dokazano i brojnim sociofonetskim istraživanjima, prihvatljivost govora jedan od uvjeta dobre integracije $\mathrm{u}$ društvo (dobivanja boljeg zaposlenja ili napredovanja). S obzirom na to da je vrijeme koje nastavnik ima na raspolaganju za izgovorne vježbe često ograničeno, u ovome se radu zastupa stajalište da se na početnim stupnjevima učenja jezika poučavanjem treba pokušati ukloniti ona odstupanja koja ometaju komunikaciju na ciljanom jeziku, odnosno ona koja otežavaju sporazumijevanje. Ponuđena klasifikacija ima stoga namjeru ponuditi jednostavan i intuitivan okvir za razvrstavanje mogućih izgovornih odstupanja na samim počecima učenja inog jezika, a izrađena je na temelju primjera usmene proizvodnje i govornog međudjelovanja 
učenika na polovici razine A1.1 (iako se pojave koje obuhvaća vjerojatno javljaju i na podrazinama A1.1 i A1.2).

Kao što je vidljivo iz tablice 6, ortoepska se odstupanja definiraju kao ona kojima je izvor u pismu. Ona mogu i ne moraju imati reperkusije na razumljivost iskaza (što ovisi o tome pruža li glasovna okolina dovoljno zalihosnih elemenata koji omogućavaju razumijevanje) te se u kontekstu hrvatskoga, koji se bilježi fonetskim pismom, odnose na jedan segment. Glavni su kriteriji za definiranje fonoloških odstupanja to što ona uzrokuju poteškoće u razumijevanju i to što se javljaju na jednom segmentu, odnosno glasu. Glavni je kriterij za definiranje koartikulacijskih odstupanja taj da se ona javljaju kada odstupanje proizlazi iz kontakta dvaju glasova koje govornik može izgovoriti kada se javljaju zasebno. Takva odstupanja mogu i ne moraju uzrokovati nerazumijevanje, ovisno opet o tome ima li u glasovnoj okolini i komunikacijskom kontekstu dovoljno zalihosnih elemenata. Naglasna odstupanja, na razini učenja o kojoj je ovdje riječ, jesu odstupanja u mjestu naglaska koja otežavaju razumijevanje, a fonetska su odstupanja ona koja neće imati utjecaja na razumljivost, ali identificiraju osobu kao neizvornoga govornika.

Predložena klasifikacija ima glotodidaktičke reperkusije jer može poslužiti kao okvir za određivanje redoslijeda otklanjanja uočenih odstupanja te za odabir odgovarajućih metoda poučavanja izgovoru. Na samome početku rada na otklanjanju izgovornih odstupanja pozornost bi trebalo posvetiti ortoepskim odstupanjima, koja bi trebalo biti najlakše otkloniti jer se ona u pravilu ne javljaju kada je grafijski sustav u potpunosti usvojen. Samo usvajanje grafijskog sustava hrvatskoga ne bi trebalo predstavljati poteškoće jer je hrvatsko pismo fonetsko, te ga je uz malo vježbe lako savladati. Fonološkim odstupanjima svakako treba posvetiti najviše pozornosti jer je riječ o odstupanjima u distinktivnim obilježjima glasova, a metode koje nastavniku stoje na raspolaganju nabrojane su u 4. poglavlju. Nakon što su u potpunosti usvojena razlikovna obilježja pojedinih glasova, može se poraditi na otklanjanju koartikulacijskih odstupanja vježbama u kojima se ciljani segment javlja u glasovnoj okolini koja uzrokuje poteškoće. Naglasnim se odstupanjima treba baviti ako uzrokuju poteškoće u komunikaciji, i to metodom ponavljanja ciljanih leksema za nastavnikom kao i korištenjem posebnih oznaka za naglasno mjesto $u$ pisanim materijalima. Fonetskim se odstupanjima, koja su definirana kao odstupanja na nedistinktivnim obilježjima, u načelu ne treba baviti u početnim fazama učenja hrvatskoga, osim ako se ne ustanovi da ometaju komunikaciju. 


\section{LITERATURA}

Banković-Mandić, I. (2012) Izgovorna obilježja učenika hrvatskoga kao drugoga i stranoga jezika na različitim stupnjevima znanja. Doktorska disertacija. Zagreb: Filozofski fakultet Sveučilišta u Zagrebu.

Banković-Mandić, I. (2013) Izgovorna kompetencija. U Grgić, A., Gulešić Machata, M. i Nazalević Čučević, I. (ur.) Hrvatski B1: Opisni okvir referentne razine B1. Zagreb: FF-press, 233-240.

Banković-Mandić, I. (2014) Fonetske vježbe za inojezične govornike hrvatskoga. U Čilaš Mikulić, M. i Juričić, A.-T. (ur.) Savjetovanje za lektore hrvatskoga kao inoga jezika, 2. zbornik radova. Zagreb: Filozofski fakultet u Zagrebu, 29-41.

Banković-Mandić, I. (2017) Izgovorna kompetencija. U Grgić, A. i Gulešić Machata, M. (ur.) Hrvatski A2: Opisni okvir referentne razine A2. Zagreb: FF press, 198-210.

Banković-Mandić, I. (2018) Izgovor hrvatskog kao inog iz perspektive izvornih govornika. Zbornik radova Šestoga hrvatskoga slavističkoga kongresa. Zagreb: Hrvatsko filološko društvo, 869-884.

Banković-Mandić, I. (2019) Samprocjena izgovora neizvornih govornika hrvatskog jezika. Strani jezici $48(1 / 2), 25-40$.

Ćatić, I. (2012) Kompetencije i kompetencijski pristup obrazovanju. Pedagogijska istraživanja. 9 (1/2), $175-187$.

Derwing, T. M. i Munro, M. J. (2015) Pronunciation Fundamentals: Evidence-based Perspectives for L2 Teaching and Research. Amsterdam / Philadelphia: John Banjamins Publishing Company.

Desnica-Žerjavić, N. (1993) Načela fonetske korekcije. Strani jezici 22 (2), 126-131.

Desnica-Žerjavić, N. (1998a) Fonetska razina jezika u dodiru. Doktorska disertacija. Filozofski fakultet Sveučilišta u Zagrebu.

Desnica-Žerjavić, N. (1998b) Klasifikacija fonetskih grešaka. Govor 15 (2), 71-101.

Desnica-Žerjavić, N. (2000) Procjena stupnja izraženosti stranog akcenta. Govor 17 (1), 1-14.

Desnica-Žerjavić, N. (2006) Strani akcent. Zagreb: FF press.

Galić, N. (2015) Fonetska korekcija izgovora hrvatskog jezika u izvornih govornika bugarskog. Diplomski rad. Filozofski fakultet Sveučilišta u Zagrebu.

Guberina, P. (1986) Lingvistika govora kao govorna osnova verbotonalnog sistema i strukturalizam u općoj lingvistici. Govor 1 (1), 3-18.

Guberina, P. (2010) Govor i čovjek: verbotonalni sistem. Zagreb: Poliklinika za rehabilitaciju slušanja i govora SUVAG - Artresor naklada.

Gulešić-Machata, M. i Udier, S. L. (2008) Izvorna odstupanja u hrvatskome kao inojezičnome. Lahor $5(1), 19-33$.

Horga, D. (2014) Guberinina fonetika u učenju izgovora. U Dulčić, A. (ur.) Aktualnost Guberinine misli u stoljeću uma: znanstveno-stručna monografija znanstveno-stručnog simpozija verbotonalnog sistema. Zagreb: Poliklinika SUVAG, 117-129.

Horga, D. i Liker, M. (2016) Artikulacijska fonetika. Anatomija i fiziologija izgovora. Zagreb: Ibis grafika. Jelaska, Z. (2005) Hrvatski kao drugi i strani jezik. Zagreb: Hrvatska sveučilišna naklada.

Moulton, W. G. (1962) Toward a Classification of Pronunciation Errors. The Modern Language Journal 46 (3), 101-109.

Nazalević Čučević, I. (2013) Opis razine B1 prema ZEROJ-u: komunikacijska kompetencija, jezične aktivnosti i strategije, kontekst korištenja jezikom, tekst. U Grgić, A., Gulešić Machata, M. i Nazalević Čučević, I. (ur.) Hrvatski B1: Opisni okvir referentne razine B1. Zagreb: FF-press, 17-33.

Pavičić Takač, V. i Bagarić Medve, V. (2013) Jezična i strategijska kompetencija u stranome jeziku. Osijek: Filozofski fakultet Sveučilišta J. J. Strossmayera u Osijeku.

Šafarić, I., Ćalušić, A. i Mildner, V. (2006) Procjena izgovora neizvornih govornika hrvatskoga jezika. Lahor 1 (1), 49-60.

Škarić, I. (2009) Hrvatski izgovor. Zagreb: Nakladni zavod Globus.

Vijeće za kulturnu suradnju; Odbor za obrazovanje; Odjel za suvremene jezike, Strasbourg. (2005) Zajednički europski referentni okvir za jezike: učenje, poučavanje, vrednovanje. Zagreb: Školska knjiga - Council of Europe.

Volenec, V. (2015) Coarticulation. U Davis, J. (ur.) Phonetics: Fundamentals, Potential Applications and Role in Communicative Disorders. New York: Nova Science Publishers, 47-86. 


\section{Mrežni izvori:}

http://hjp.znanje.hr/?show=kratice_jezici (9.4. 2020.)

http://web.phonetik.uni-frankfurt.de/upsid_segment_freq.html (9.4. 2020.)

https://www.internationalphoneticassociation.org/content/ipa-diacritics (9. 4. 2020.)

https://www.internationalphoneticalphabet.org/html-ipa-keyboard-v1/keyboard/ (9. 4. 2020.)

\section{CLASSIFICATION OF PRONUNCIATION ERRORS ON BEGINNERS' LEVEL OF LEARNING CROATIAN - GLOTTODIDACTIC APPROACH}

Contemporary approach to L2 teaching is focused on acquiring communication competence, which also comprises pronunciation. In order to achieve appropriate pronunciation competence, it is important to correct pronunciation errors, which can be systematically approached, primarily through their description, analysis and classification. This paper tries to offer a simple classification of pronunciation errors, which could be applied on pronunciation of Croatian as L2 (regardless of the students' source language). Various phenomena on the beginners' level of learning can be integrated into this classification. Examples of errors are excerpted from the recordings of spoken production and spoken interaction after $30-45$ hours of formal learning of Croatian as L2. The classified and described phenomena can be expected on A1.1 and A1.2 learning sub-levels and are divided into orthoepic, phonological, coarticulatory, phonetic and accent errors. This division offers a framework for deciding on the order of correcting errors as well as for choosing appropriate methods of teaching.

Keywords: pronunciation errors, Croatian as L2, phonological errors, phonetic errors.

This work is licensed under a Creative Commons Attribution 4.0 International License.

Ovaj rad dostupan je za upotrebu pod licencom Creative Commons Imenovanje 4.0 međunarodna. 